\title{
Response of Branching and Nonbranching Cut Flower Cultivars of Sunflower to Pinching and Planting Density
}

\author{
Hans C. Wien ${ }^{1}$
}

ADDITIONAL INDEX WORDS. flower value, pinching time, Septoria belianthi

\begin{abstract}
Summary. Pinching sunflower (Helianthus annums) grown for cut flowers in the vegetative stage increases stem yield at least 3 -fold. Four experiments were conducted to further investigate the cultivar response differences to pinching, to explore the response to planting density, and to examine the effect of the time of pinching. In the first two experiments, two branching and one nonbranching cultivar in 2011, and three branching cultivars in 2012, were grown at $6 \times 6$-, $9 \times 9$-, and $12 \times 12$-inch spacing and pinched at the six-leaf stage. Pinching led to stem yield increases, but reduced flower size and stem length. Combining closer spacing with pinching further decreased flower size, increased the number of stems, and the gross value of stems per unit area. At highest densities flowers were too small to be saleable. The inverse relationship of flower size to stem numbers per unit area held true across all cultivars in both years. The branching cultivar Starburst Lemon Aura was the most productive of the cultivars tested when pinched, yielding 15,744 stems/1000 $\mathrm{ft}^{2}$ at the closest spacing. In 2013 and 2015, delaying the time of pinching from the 6-leaf to the 10-leaf stage reduced stem production among three nonbranching cultivars from 2.8 to 1.8 stems/plant, compared with an increase from 4.2 to 5.1 stems/plant for the branching cultivar Goldrush. The difference in pinching response among cultivars in 2013 and 2015 may have been related to relative severity of septoria leaf blight (Septoria helianthi) that infected the lower leaves. The results of the four experiments confirmed the efficacy of pinching on productivity and value of sunflowers, with best results obtained when pinching was done at the six-leaf stage.
\end{abstract}

$\mathrm{I}$ $\mathrm{n}$ previous studies, pinching of nonbranching sunflower cultivars in the seedling stage led to a more than 3-fold increase in stem production (Wien, 2016). Many sunflower cultivars developed for cut flower use produce more than one stem, and are termed branching cultivars (Armitage and Laushman, 2003). The response of oilseed cultivars (Majid and Schneiter, 1987; Robinson et al., 1980) and cut flower sunflower (Wien, 2016) to planting density have been well documented; however, the interaction between planting density and pinching is not well understood for cut flower cultivars contrasting in branching habit.

It is also unclear how timing of pinching affects the growth of cut flower sunflower. Results with singlestem oil seed cultivars indicated that delaying pinching into early or later reproductive period was detrimental to growth and seed yield (Schneiter

Horticulture Section, School of Integrative Plant Science, Plant Science Hall, Cornell University, Ithaca, NY 14853

${ }^{1}$ Corresponding author. E-mail: hcw2@cornell.edu.

doi: 10.21273/HORTTECH03622-17 and Johnson, 1994). Although Sloan and Harkness (2010) performed pinching studies on cut sunflower, it was not clear at what age the plants were pinched. In previous studies (Wien, 2016), apices were removed when the plants had only four to six leaves longer than $4 \mathrm{~cm}$ [V4 to V6 growth stages (Berglund, 2007)]. At this stage, the nodes are crowded together, making apex removal without defoliation difficult. To determine if pinching could be delayed until nodes were far enough apart to allow mechanical pinching, two experiments were conducted to test the importance of timing of the apex removal on four sunflower cultivars.

\section{Materials and methods}

All four experiments were conducted in an experimental field near Ithaca, NY (lat. $42.42^{\circ} \mathrm{N}$, long. $76.50^{\circ} \mathrm{W}$ ), having sandy loam soil (coarse-loamy, mixed, active, mesic Lamellic Hapludalf). The soil was fertilized yearly in spring with inorganic fertilizer containing 60,13 , and $25 \mathrm{lb} /$ acre of nitrogen $(\mathrm{N})$, phosphorus $(\mathrm{P})$, and potassium $(\mathrm{K})$, respectively. Beds 4 inches high and 40 inches wide were formed, watered by two trickle irrigation lines, and covered with black polyethylene mulch. Irrigation lines had emitters spaced at 8 inches, with a flow rate of $1 \mathrm{gal} / \mathrm{min} / 100 \mathrm{ft}^{2}$ (Belle Terre Irrigation, Sodus, NY). Irrigation was used if rainfall was less than $l$ inch per week, for an 8-h application period.

In 2011, seeds of two branching ('Starburst Lemon Éclair' and 'Goldrush') and one nonbranching sunflower ('Procut Amber Glow') were sown in a greenhouse in seedling trays with $55-\mathrm{mL}$ individual cell volume filled with $50 \%$-peat, $50 \%$-vermiculite artificial soil mix, prepared locally. During the seedling growth period, greenhouse temperatures were maintained at $24 \pm 2{ }^{\circ} \mathrm{C}$, and trays were fertilized with a $15 \mathrm{~N}-2.2 \mathrm{P}-12.5 \mathrm{~K}$ nutrient solution at the rate of $150 \mathrm{mg} \cdot \mathrm{L}^{-1} \mathrm{~N}$ during weekdays and water on weekends.

In the field, three plant arrangements were compared: $6 \times 6$-inch spacing in six rows per 4-ft-long bed, $9 \times 9$-inch spacing with four rows per 4.5 -ft-long bed, and $12 \times 12$-inch spacing with three rows per 4 -ft-long bed. The experimental design was a split-split plot, with pinching treatments as main plots, cultivars as subplots, and spacing as sub-subplots. There were three replications, with a sowing date of 11 May and transplant date of 3 June. Plants were pinched by hand on 15 June, leaving six leaves.

\begin{tabular}{llll}
\hline $\begin{array}{l}\text { Units } \\
\text { To convert U.S. to SI, } \\
\text { multiply by }\end{array}$ & U.S. unit & SI unit & $\begin{array}{l}\text { To convert SI to U.S., } \\
\text { multiply by }\end{array}$ \\
\hline 29.5735 & $\mathrm{fl} \mathrm{oz}$ & $\mathrm{mL}$ & 0.0338 \\
0.3048 & $\mathrm{ft}$ & $\mathrm{m}$ & 3.2808 \\
0.0929 & $\mathrm{ft}^{2}$ & $\mathrm{~m}^{2}$ & 10.7639 \\
3.7854 & gal & $\mathrm{L}$ & 0.2642 \\
2.54 & inch $(\mathrm{es})$ & $\mathrm{cm}$ & 0.3937 \\
1.1209 & lb/acre & $\mathrm{kg} \cdot \mathrm{ha}^{-1}$ & 0.8922 \\
1 & $\mathrm{ppm}$ & $\mathrm{mg} \cdot \mathrm{L}^{-1}$ & 1 \\
$\left({ }^{\circ} \mathrm{F}-32\right) \div 1.8$ & ${ }^{\circ} \mathrm{F}$ & ${ }^{\circ} \mathrm{C}$ & $\left({ }^{\circ} \mathrm{C} \times 1.8\right)+32$
\end{tabular}


Individual shoots or branches were harvested at anthesis, defined as the time when the majority of petals (ray flowers) had just unfolded to an angle of $90^{\circ}$ or more to the disk. Shoot length was measured from soil level to the top of the flower head for unpinched controls, and from the base of each branch to the top of the flower head for the pinched plants. Flower disk diameter was measured as the distance across the disk, ignoring petals. Leaf numbers included abscised leaves indicated by leaf scars at the stem base for controls, and leaves near the head that had visible petioles. To avoid edge effects, only the inner single, double, or four rows (for $12 \times$ $12-, 9 \times 9$-, and $6 \times 6$-inch spacing, respectively) were harvested as yield samples. Statistical analysis of the data was conducted using Statistix software (version 9; Analytical Software, Tallahassee, FL), using analysis of variance to analyze main effects and interactions and Duncan's multiple range test for means separations.

The 2012 experiment was conducted on an adjacent area in the same field. Treatments and experimental design were the same, except that the cultivars were the three branching cultivars Starburst $\mathrm{Pa}$ nache, Goldrush, and Greenburst. The first two replications were sown on 13 June in the greenhouse, and transplanted on 2 July; the third replication followed on 27 June and 13 July, respectively. Statistical analysis was conducted as for the 2011 experiment.

Economic values of the harvested flowers were calculated using wholesale prices posted for the Boston wholesale flower market, assuming that flowers with disks less than $4 \mathrm{~cm}$ diameter were not saleable, 4 to $6 \mathrm{~cm}$ corresponded to the market designation of "small" ( $\$ 0.85 /$ stem $)$, 6 to $8 \mathrm{~cm}$ to "medium" $(\$ 1.00 /$ stem), and more than $8 \mathrm{~cm}$ to "large" (\$1.50/stem) [U.S. Department of Agriculture (USDA), 2016]. Values were obtained by multiplying yields by prices according to the flower diameter. The economic value analysis was conducted for the 2011 and 2012 experiments, only for 'Goldrush', a standard sunflower with orange petals and brown disk color. Normal pricing may not apply to the unusual "semidouble" flower appearance of the other two cultivars.

The time of pinching trials was carried out in 2013 and 2015. The apex was removed with pruners leaving either 6 or 10 leaves. The singlestem cultivars Procut Lemon, Procut Gold, Sunrich Orange, and the branching cultivar Goldrush were grown at $9 \times 9$-inch spacing in four rows on 40 -inch beds covered with black polyethylene mulch. Plots consisted of 20 plants in 2013 and 24 plants in 2015. Experimental design was a split plot with pinching treatments as main plots and cultivars as subplots. There were three replications. The plants were started in 72 cell trays on 17 July in 2013, and transplanted on 14 Aug., with pinching taking place on 23 and $28 \mathrm{Aug}$. for the 6-leaf and 10-leaf treatments, respectively. Fertility management practices in greenhouse and field were the same as in the 2011 and 2012 experiments. In 2015, seeds were sown on 20 May and transplanted on 10 June, with pruning treatments on 22 and 27 June. Although two of the cultivars used in this study are hastened to flower by short days in the seedling stage (Wien, 2014), seedlings experienced long days in both studies in spite of the differing sowing times. Statistical analysis was done on each year's data separately, using Statistix software.

\section{Results and discussion}

Pinching in the vegetative stage induced the sunflower plant to form branches, increasing plant yield but reducing flower diameter and stem length (Table 1 ) as found in previous work (Wien, 2016). The decreased flower size after pinching was at least partly due to the effect of crowding. When unpinched plants were spaced more closely, a similar decrease in flower size also occurred. The stem density-flower size relationship was shown to be continuous across spacing and pinching treatments in 2011 (Fig. 1), and in 2012 (not shown), as well as in previous work on pinching (Wien, 2016).

Stem length was reduced $54 \%$ by pinching across the two experiments, but was unaffected by spacing (Table 1 ). Pinching stimulated stem production, and branching increased more at the wider spacing, leading to a highly significant pinching by spacing interaction.

Choice of cultivar significantly influenced the response to pinching in both experiments (Tables 2 and 3 ). In 2011, the unbranched 'Procut Amber Glow' had longer stems when not pinched than the two branched cultivars, but similar stem lengths to

Table 1. The effect of pinching and spacing on stem length, flower diameter, and yield of stems per plant of sunflower in 2011 and 2012. Plants were pinched (apical meristem removed) in the vegetative stage when plants had six leaves. Values are averages of two branching and one single-stem cultivar in 2011, and three branching cultivars in 2012. Statistical analysis was done separately for each year.

\begin{tabular}{|c|c|c|c|c|c|c|c|}
\hline \multirow[b]{2}{*}{ Pinch treatment } & \multirow[b]{2}{*}{ Spacing (inches) $)^{\mathrm{z}}$} & \multicolumn{2}{|c|}{ Stem length $(\mathrm{cm})^{\mathrm{z}}$} & \multicolumn{2}{|c|}{ Flower diam $(\mathrm{cm})$} & \multicolumn{2}{|c|}{ Stems (no./plant) } \\
\hline & & 2011 & 2012 & 2011 & 2012 & 2011 & 2012 \\
\hline \multirow[t]{2}{*}{ Not pinched } & $6 \times 6$ & $131 a^{y}$ & $144 \mathrm{a}$ & $4.9 \mathrm{c}$ & $4.8 \mathrm{c}$ & $1.0 \mathrm{c}$ & $1.0 \mathrm{~d}$ \\
\hline & $12 \times 12$ & $121 \mathrm{~b}$ & 138 a & $6.2 \mathrm{a}$ & $6.7 \mathrm{a}$ & $1.0 \mathrm{c}$ & $1.1 \mathrm{~d}$ \\
\hline \multirow[t]{2}{*}{ Pinched } & $6 \times 6$ & $70 \mathrm{c}$ & $64 c$ & $3.1 \mathrm{e}$ & $3.7 \mathrm{~d}$ & $3.0 \mathrm{~b}$ & $2.4 \mathrm{c}$ \\
\hline & $9 \times 9$ & $75 \mathrm{c}$ & $72 \mathrm{bc}$ & $3.9 \mathrm{~d}$ & $4.2 \mathrm{~d}$ & $3.6 \mathrm{ab}$ & $4.3 \mathrm{~b}$ \\
\hline
\end{tabular}

${ }^{\mathrm{z}} 1$ inch $=2.54 \mathrm{~cm}, \mathrm{l} \mathrm{cm}=0.3937$ inch

yalues in columns followed by the same letters are not significantly different at the $5 \%$ level using Duncan's multiple range test.

$*, * *, * * *$ Significant $\mathrm{F}$ test at $P \leq 0.05,0.01,0.001$ level, respectively. 
Goldrush when pinched. 'Starburst Lemon Aura' stems were shortest in both pinching treatments (Table 2). Flower diameter was proportional to

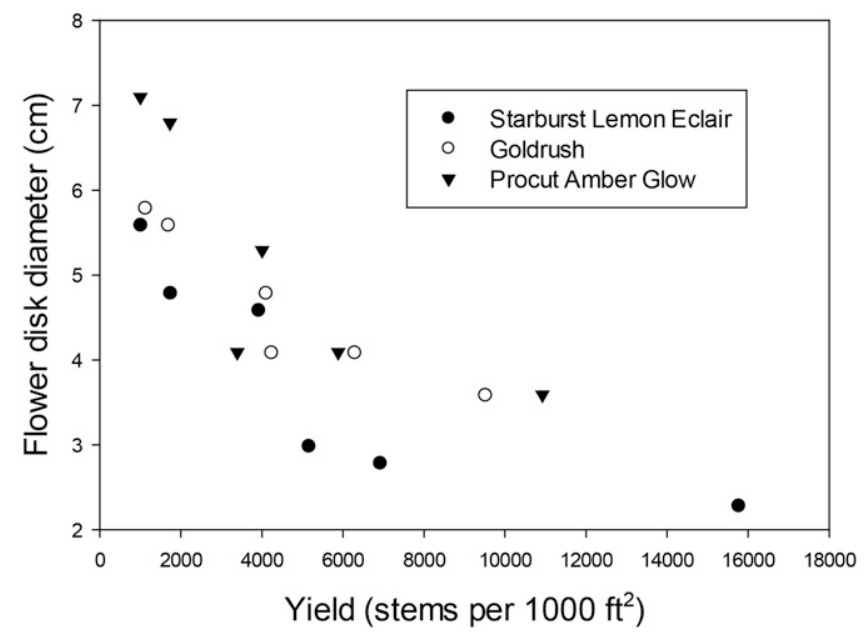

Fig. 1. The relationship of flower disk diameter and stem yield of three cultivars of sunflower grown at three plant spacings and either pinched (apical meristem removed) at the six-leaf stage, or allowed to grow without pinching in the 2011 experiment. 'Procut Amber Glow' was the only nonbranching cultivar; 1 stem/ $1000 \mathrm{ft}^{2}=10.7639$ stems $/ 1000 \mathrm{~m}^{2}, 1 \mathrm{~cm}=0.3937$ inch.
Pinching stimulated more branching in 'Starburst Lemon Aura' than in the other two cultivars, a difference that was maintained at all three spacings, leading to a significant threeway interaction (Table 4). Pinched 'Procut Amber Glow' produced the fewest branches at the widest spacing compared with the two branching cultivars. In a comprehensive pinching study in Mississippi, Sloan and Harkness (2010) also found cultivar differences among sunflowers, with branching cultivars producing more stems than those normally not branching.

In the 2012 study, there were no significant differences among cultivars in terms of flower diameter and yield per plant (Table 3 ). Stem yields averaged 9600 stems $/ 1000 \mathrm{ft}^{2}$ at the $6 \times 6$-inch spacing when pinched (not shown).

Although pinching and close spacing increased the yield of flower stems, the market value of those flowers could be questioned. By comparing data on flower diameter, yield,

Table 2. Effect of pinching and cultivar on stem length, flower diameter, and yield of stems per plant in the 2011 sunflower pinching experiment. Plants were pinched (apical meristem removed) in the vegetative stage, leaving six leaves. Values are averaged across the three spacing treatments of $6 \times 6,9 \times 9$, and $12 \times 12$ inches. The three-way interaction of pinching, cultivar and spacing was not significant for the three variables.

\begin{tabular}{llccc}
\hline Pinch treatment & \multicolumn{1}{c}{ Cultivar } & Stem length $(\mathbf{c m})^{\mathrm{z}}$ & Flower diam $(\mathrm{cm})$ & Stems $(\mathbf{n o} \cdot /$ plant $)$ \\
\hline Not pinched & Starburst Lemon Aura & $112 \mathrm{c}^{\mathrm{y}}$ & $5.0 \mathrm{~b}$ & $5.4 \mathrm{~b}$ \\
& Goldrush & $123 \mathrm{~b}$ & $6.4 \mathrm{a}$ & $1.0 \mathrm{c}$ \\
& Procut Amber Glow & $142 \mathrm{a}$ & $2.8 \mathrm{~d}$ & $4.0 \mathrm{c}$ \\
Pinched & Starburst Lemon Aura & $47 \mathrm{e}$ & $4.0 \mathrm{c}$ & $3.3 \mathrm{a}$ \\
& Goldrush & $88 \mathrm{~d}$ & $4.2 \mathrm{c}$ & $3.1 \mathrm{~b}$ \\
Procut Amber Glow & $85 \mathrm{~d}$ & $* *$ & $*$
\end{tabular}

${ }^{\mathrm{z}} 1$ inch $=2.54 \mathrm{~cm}, 1 \mathrm{~cm}=0.3937$ inch.

'Values in columns followed by the same letters are not significantly different at the $5 \%$ level using Duncan's multiple range test.

$*, * *, * *$ Significant $\mathrm{F}$ test at $P \leq 0.05,0.01,0.001$ level, respectively.

Table 3. Effect of pinching and cultivar on stem length, flower diameter, and yield of stems per plant in the 2012 sunflower pinching experiment. Plants were pinched (apical meristem removed) in the vegetative stage, leaving six leaves. Values are averaged across the three spacing treatments of $6 \times 6,9 \times 9$, and $12 \times 12$ inches. The three-way interaction of pinching, spacing and cultivar was not significant for the three variables.

\begin{tabular}{llccc}
\hline Pinch treatment & \multicolumn{1}{c}{ Cultivar } & Stem length $(\mathbf{c m})^{\mathrm{z}}$ & Flower diam $(\mathrm{cm})$ & Stems $(\mathbf{n o .} /$ plant $)$ \\
\hline Not pinched & Starburst Panache & $150 \mathrm{a}^{\mathrm{y}}$ & 6.0 & 5.2 \\
& Goldrush & $123 \mathrm{~b}$ & 6.3 & 1.0 \\
& Greenburst & $153 \mathrm{a}$ & 3.9 & 1.1 \\
Pinched & Starburst Panache & $63 \mathrm{c}$ & 3.9 & 4.2 \\
& Goldrush & $72 \mathrm{c}$ & 4.2 & 4.1 \\
& Greenburst & $74 \mathrm{c}$ & NS & NS \\
\hline
\end{tabular}

${ }^{\mathrm{z}} \mathrm{l}$ inch $=2.54 \mathrm{~cm}, \mathrm{l} \mathrm{cm}=0.3937$ inch.

yalues in columns followed by the same letters are not significantly different at the $5 \%$ level using Duncan's multiple range test.

ss, ${ }^{* *}$ Nonsignificant at $P \leq 0.05$ and significant $F$ test at $P \leq 0.01$ level. 
Table 4. The interaction of pinching and spacing on the yield per unit area of two branching cultivars (Starburst Lemon Éclair and Goldrush) and one single-stem cultivar (Procut Amber Glow) of sunflower in the 2011 experiment. Plants were pinched (apical meristem removed) in the vegetative stage, leaving six leaves. The three-way interaction was significant at the $1 \%$ level.

\begin{tabular}{|c|c|c|c|}
\hline \multirow[b]{2}{*}{ Spacing (inches) ${ }^{\mathrm{z}}$} & \multirow[b]{2}{*}{ Cultivar } & Not pinched & Pinched \\
\hline & & \multicolumn{2}{|c|}{ Stems $\left(\text { no. } / 1000 \mathrm{ft}^{2}\right)^{\mathrm{z}}$} \\
\hline \multirow[t]{3}{*}{$6 \times 6$} & Starburst Lemon Aura & $3,905 \mathrm{de}^{\mathrm{y}}$ & 15,744 a \\
\hline & Goldrush & $4,083 \mathrm{de}$ & $9,500 \mathrm{~b}$ \\
\hline & Procut Amber Glow & $4,000 \mathrm{de}$ & $10,917 \mathrm{~b}$ \\
\hline \multirow[t]{3}{*}{$9 \times 9$} & Starburst Lemon Aura & $1,729 \mathrm{e}$ & $6,904 \mathrm{c}$ \\
\hline & Goldrush & $1,679 \mathrm{e}$ & $6,272 \mathrm{c}$ \\
\hline & Procut Amber Glow & $1,729 \mathrm{e}$ & $5,876 \mathrm{~cd}$ \\
\hline \multirow[t]{3}{*}{$12 \times 12$} & Starburst Lemon Aura & $944 \mathrm{e}$ & $5,144 \mathrm{~cd}$ \\
\hline & Goldrush & $1,111 \mathrm{e}$ & $4,222 \mathrm{~cd}$ \\
\hline & Procut Amber Glow & $1,000 \mathrm{e}$ & 3,389 de \\
\hline
\end{tabular}

${ }^{\mathrm{z}} 1$ inch $=2.54 \mathrm{~cm}, 1 \mathrm{stem} / 1000 \mathrm{ft}^{2}=10.7639 \mathrm{stems} / 1000 \mathrm{~m}^{2}$.

${ }^{y}$ Values followed by the same letters are not significantly different at the $5 \%$ level using Duncan's multiple range test.

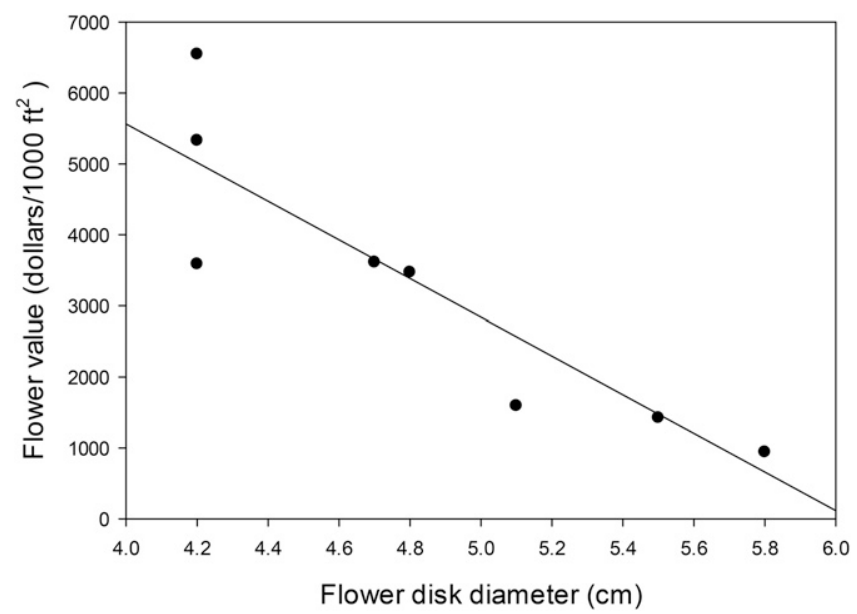

Fig. 2. The relationship of flower disk diameter of 'Goldrush' sunflower to the value per unit area of the harvested flowers in the 2011 and 2012 experiments. Flower disk diameter corresponded to the small category [4 to $6 \mathrm{~cm}$ diameter, $\$ 0.85 /$ stem (U.S. Department of Agriculture, 2016)]. Treatments producing flowers with disk diameters less than $4 \mathrm{~cm}$ were judged unmarketable and thus valueless and have not been included in this figure. Line equation: $y=15,472-2539 x, r=0.903 * * ; \$ 1 / 1000 \mathrm{ft}^{2}=\$ 10.7639 / 1000 \mathrm{~m}^{2}$, $1 \mathrm{~cm}=0.3937$ inch. and value for 'Goldrush' in the 2011 and 2012 experiments, a similar inverse relationship between flower size and value per unit area was obtained as in previous studies (Fig. 2) (Wien, 2016). The highest yields were obtained by combining pinching and close spacing. However, gross values dropped to zero as flower diameter diminished below the minimum marketable diameter of $4 \mathrm{~cm}$ in this treatment, indicating that there are limits to economic yields of sunflower (USDA, 2016).

Removal of a sunflower's growing point (pinching) is more easily accomplished when plants have many nodes, and the stem has elongated. However, by delaying the pinching $5 \mathrm{~d}$, and leaving 10 instead of 6 leaves, stem length, leaves per stem, and flower disk diameter were significantly decreased in both 2013 and 2015 (Tables 5 and 6). Stem length was reduced to $44 \%$ and $62 \%$ of controls with pinching at leaf 6 , and to $31 \%$ and $42 \%$ for pinching at leaf 10 in 2013 and 2015, respectively (Tables 5 and 6). The number of leaves produced by these stems was also reduced, since they were formed at higher main stem nodes. A similar reduction in node numbers of branches formed at upper compared with lower main stem nodes was also noted by Faust (2006) for nemesia (Nemesia strumosa), and by Inaba et al. (2010) for snapdragon (Antirrbinum majus). The stem length and leaf number decline were generally not accompanied by a decrease in flower diameter with later pinching (Tables 5 and 6 ).

Although these changes with late pinching held true generally across cultivars, the branching cultivar Goldrush showed less reduction in stem length than the nonbranching

Table 5. Stem length, leaf number per stem, flower disk diameter, and yield of stems at flowering of three single-stem cultivars (Procut Lemon, Procut Gold, and Sunrich Orange) and one branching cultivar (Goldrush) of sunflower grown in 2013. Plants were either not pinched or pinched (apex removed) in the vegetative stage, leaving either 6 or 10 leaves.

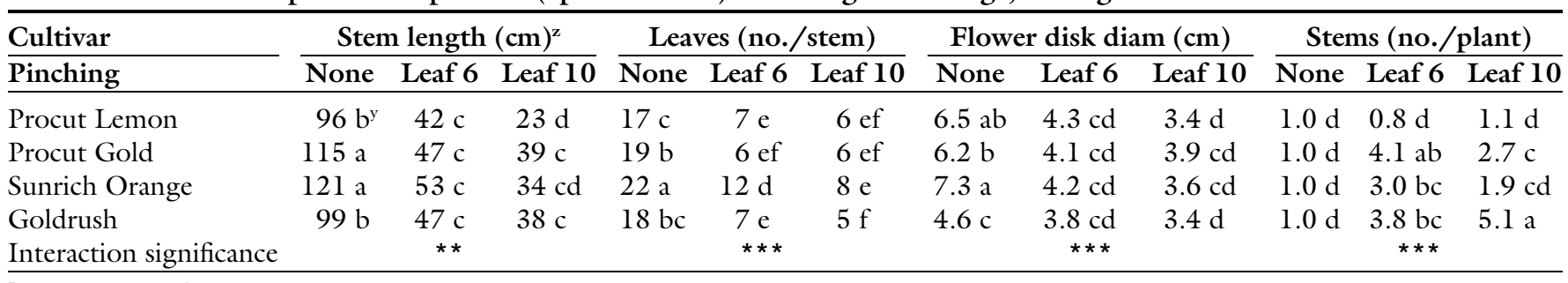

${ }^{\mathrm{z}} 1 \mathrm{~cm}=0.3937$ inch.

y Values in three-column sets for each variable followed by the same letters are not significantly different at the $5 \%$ level using Duncan's multiple range test.

$* *, * * *$ Significant $\mathrm{F}$ test at $P \leq 0.01,0.001$ level, respectively. 
Table 6. Stem length, leaves per stem, flower disk diameter, and yield of harvested stems per plant of three single-stem cultivars (Procut Lemon, Procut Gold, and Sunrich Orange), and one branching cultivar (Goldrush) of sunflower grown in 2015. Plants were either not pinched or pinched (apex removed) during the vegetative stage leaving either 6 or 10 leaves.

\begin{tabular}{|c|c|c|c|c|c|c|c|c|c|c|c|c|}
\hline \multirow{2}{*}{$\begin{array}{l}\text { Cultivar } \\
\text { Pinching }\end{array}$} & \multicolumn{3}{|c|}{ Stem length $(\mathrm{cm})^{\mathrm{z}}$} & \multicolumn{3}{|c|}{ Leaves (no./stem) } & \multicolumn{3}{|c|}{ Flower disk diam $(\mathrm{cm})$} & \multicolumn{3}{|c|}{ Stems (no./plant) } \\
\hline & None & Leaf 6 & Leaf 10 & None & Leaf 6 & Leaf 10 & None & Leaf 6 & Leaf 10 & None & Leaf 6 & Leaf 10 \\
\hline Procut Lemon & $128 c^{y}$ & $72 \mathrm{f}$ & $49 \mathrm{~h}$ & $18 \mathrm{c}$ & $8 \mathrm{gh}$ & $7 \mathrm{~h}$ & $8.0 \mathrm{~b}$ & $4.4 \mathrm{~d}$ & $3.5 \mathrm{e}$ & $1.0 \mathrm{f}$ & $2.8 \mathrm{~cd}$ & $2.3 \mathrm{~d}$ \\
\hline Sunrich Orange & $168 \mathrm{a}$ & $99 \mathrm{~d}$ & $55 \mathrm{gh}$ & $26 a$ & $16 \mathrm{~d}$ & $9 \mathrm{fg}$ & $9.2 \mathrm{a}$ & $5.9 \mathrm{c}$ & $4.5 \mathrm{~d}$ & $1.0 \mathrm{f}$ & $3.2 \mathrm{c}$ & $1.7 \mathrm{e}$ \\
\hline Goldrush & $125 \mathrm{c}$ & $86 \mathrm{e}$ & $74 \mathrm{f}$ & $20 \mathrm{~b}$ & $11 \mathrm{e}$ & $8 \mathrm{gh}$ & $5.9 \mathrm{c}$ & $4.3 \mathrm{~d}$ & $4.1 \mathrm{~d}$ & $1.0 \mathrm{f}$ & $4.7 \mathrm{~b}$ & $5.6 \mathrm{a}$ \\
\hline Interaction significance & & *** & & & $* * *$ & & & $* * *$ & & & $\star * *$ & \\
\hline
\end{tabular}

${ }^{\mathrm{z}} 1 \mathrm{~cm}=0.3937$ inch.

yValues in three-column sets for each variable followed by the same letters are not significantly different at the $5 \%$ level using Duncan's multiple range test.

${ }^{* * *}$ Significant $\mathrm{F}$ test at $P \leq 0.001$ level.

cultivars (Tables 5 and $\mathbf{6}$ ). 'Goldrush' also produced more stems when pinched at node 10, whereas branching decreased greatly in the nonbranching cultivars (Tables 5 and 6 ).

A major contributing factor in the reduced stem production with late pinching of the nonbranching cultivars in the 2013 and 2015 trials could have been the occurrence of septoria leaf blight on the main stem lower leaves (Tosi and Zazzerini, 1989). No formal ratings of disease incidence were made in the experiments, but informal observations noted heavy septoria leaf blight incidence in pinched 'Procut Lemon' in 2013, and in late-pinched 'Procut Lemon', 'Procut Gold', and 'Sunrich Orange' in 2015 (Fig. 3). 'Goldrush' was less affected by the disease after pinching at node 10. Plants not pinched had infected lower leaves but showed little disease incidence on the upper canopy leaves (Fig. 3). The heavier disease pressure in 2015 could have been aided by rainfall totals of 6.6 and 4.9 inches in June and July, respectively, which were $65 \%$ and $29 \%$ above the monthly 30 -year averages (Northeast Regional Climate Center, 2016).

Plants that have been pinched are reliant on the lower main stem leaves to provide the energy to form new branches, but these leaves were also the ones most affected by septoria leaf blight (Markell et al., 2005). The disease also develops more in older plants, so later pinching would be more detrimental to leaf function. The disease could therefore delay branching and hence flowering on those branches.

Taken together these studies confirm the potential of pinching to increase sunflower yields. When

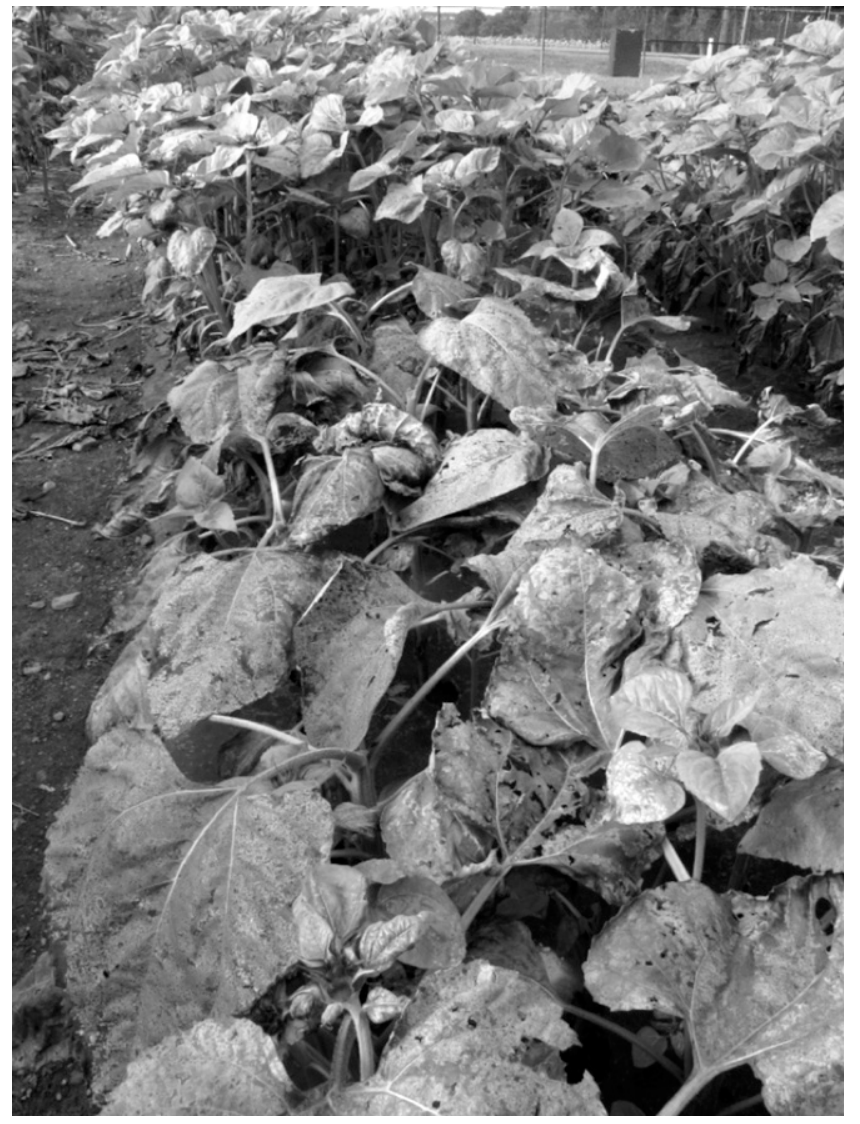

Fig. 3. 'Procut Lemon' sunflower growing in the time of pinching trial, with pinched plants in the foreground, and unpinched plants further back. Picture was taken on 17 July 2015, $10 \mathrm{~d}$ after the pinch at leaf 10 . Note the diseased main stem leaves in foreground plants, and diseased lower, and less affected upper leaves in the background.

combined with higher plant populations, plants produced up to 10 stems $/ \mathrm{ft}^{2}$. Although such small blooms command a lower price on the wholesale market (USDA, 2016), the gross value still exceeded that earned for lower yields of larger flowers (Fig. 2) (Wien, 2016). The primary difference among cultivars in response to pinching appears to relate primarily to branching tendency.
Branching cultivars maintain productivity when pinched late, whereas nonbranching cultivars produce few branches if pinching is delayed to the 10-leaf stage. Schneiter and Johnson (1994) showed similar yield declines with late pinching of single-stem oilseed sunflowers. Since pinching is difficult to mechanize when practiced in the early vegetative stage, the technique may be confined to small 


\section{Research Reports}

plantings in which it can be done manually, or done later on branching cultivars.

\section{Literature cited}

Armitage, A.M. and J.M. Laushman. 2003. Specialty cut flowers. 2nd ed. Timber Press, Portland, OR.

Berglund, D.R. (ed.). 2007. Sunflower production. North Dakota Agr. Expt. Sta. Publ. A-1331.

Faust, J.E. 2006. Building the plant chassis with manual and chemical pinching. OFA Bul. 896:21-24.

Inaba, Z., C. Kato, and S. Murakami. 2010. Effect of pinching node positions on the growth and flowering of snapdragons (Antirrhinum majus). Hort. Res. (Japan) 9:351-356.
Majid, H.R. and A.A. Schneiter. 1987. Yield and quality of semidwarf and standardheight sunflower hybrids grown at five plant populations. Agron. J. 79:681684.

Markell, S., R. Harveson, C. Block, and T. Gulya. 2005. Sunflower disease diagnostic series. North Dakota State Univ. Ext. Serv. Publ. PP1727-19.

Northeast Regional Climate Center. 2016. The Ithaca climate page. 3 Nov. 2016. <http://www.nrcc.cornell.edu/ wxstation/ithaca/ithace.html>.

Robinson, R.G., J.H. Ford, W.E. Lueschen, D.L. Rabas, L.J. Smith, D.D. Warnes, and J.V. Wiersma. 1980. Response of sunflower to plant population. Agron. J. 72:869-871.

Schneiter, A.A. and B.L. Johnson. 1994. Response of sunflower plants to physical injury. Can. J. Plant Sci. 36:727-729.

Sloan, R.C. and S.S. Harkness. 2010. Planting date and pinch treatments affect growth of field-grown cut flower sunflower cultivars. Mississippi Agr. For. Expt. Sta. Bul. 1180.

U.S. Department of Agriculture (USDA). 2016. Boston ornamental terminal prices. 1 June 2016. <http://www.ams.usda. gov/mnreports/bh.fx20l.txt $>$.

Tosi, L. and A. Zazzerini. 1989. Septoria helianthi Ell. And Kell., a new parasite of sunflower in Italy. Inf. Fitopatol. 39:4344.

Wien, H.C. 2014. Screening ornamental sunflowers in the seedling stage for flowering reaction to photoperiod. HortTechnology 20:575-579.

Wien, H.C. 2016. Pinching ornamental sunflowers increases cut stem yield and reduces flower size. HortTechnology 26:762766. 